\title{
Effects of population disjunction on isozyme variation in the widespread Pilgerodendron uviferum
}

\author{
A. C. PREMOLI*†, C. P. SOUTO†, T. R. ALLNUTT† \& A. C. NEWTON\$ף \\ $\dagger$ Centro Regional Universitario Bariloche, Universidad Nacional del Comahue, Quintral 1250, 8400 Bariloche, \\ Argentina, $₫$ Applied Genetics, John Innes Centre, Norwich, NR4 7UH, U.K. and §Institute of Ecology and Resource \\ Management, University of Edinburgh, Darwin Building, Kings Buildings, Mayfield Rd., Edinburgh, EH9 3JU, U.K.
}

Geographical range is considered a good predictor of the levels of isozyme variation in plants. Widespread species, often consisting of historically larger and more continuous populations, maintain higher polymorphism and are less affected by drift, which tends to erode genetic variation in more geographically restricted species. However, widespread species occurring in small and disjunct populations may not fit this pattern. In this study we examined genetic variation in Pilgerodendron uviferum, a conifer endemic to temperate forests of southern South America, and is such a widespread and habitat-restricted species. Twenty populations along the whole range of Pilgerodendron were analysed by isozyme electrophoresis to resolve 14 putative genetic loci. Eleven were polymorphic in at least one population although only six of them were polymorphic in more than one population. We found reduced within-population levels of isozyme variation, with only $11 \%$ polymorphic loci (0.95 criterion), 1.2 mean number of alleles per locus, and mean observed and expected heterozygosities of 0.024 and 0.033 , respectively. Most genetic diversity was found within populations $\left(H_{\mathrm{T}}=0.039, H_{\mathrm{S}}=0.033, F_{\mathrm{ST}} 15 \%\right)$. Greater polymorphism and lower divergence was estimated in the more geographically restricted and closely related Fitzroya. Thus, total range, in combination with information on the degree of among-population isolation, may be a better predictor of the levels of polymorphism than range size alone.

Keywords: ciprés de las Guaitecas, conifer, Cupressaceae, Patagonia, Pilgerodendron.

\section{Introduction}

Throughout the history of a given species, evolutionary forces acting in combination with its particular life history traits, shape its genetic characteristics as measured by the degree of polymorphism and population genetic divergence. Geographical range has been shown to be a good predictor of the levels of allozyme variation in plants (Karron, 1987; Hamrick \& Godt, 1989; Hamrick et al., 1992; Gitzendanner \& Soltis, 2000). Thus, geographically restricted species, usually consisting of small, isolated populations, are more susceptible to losses of genetic variation due to genetic drift and restricted gene flow (Hamrick \& Godt, 1989). However, widespread species consisting of disjunct populations may have less polymorphism and greater among-

\footnotetext{
*Correspondence. E-mail: apremoli@crub.uncoma.edu.ar

$\uparrow$ Present address: UNEP-World Conservation Monitoring Centre, 219 Huntington Road, Cambridge CB3 0DL, U.K.
}

population genetic divergence than those having more continuous populations.

The purpose of this study was to examine amounts and distribution of genetic variation in Pilgerodendron uviferum (D. Don) Florin (Cupressaceae), a widespread and habitat-restricted species, occurring in isolated populations. The hypothesis is tested that the total range of a given species, in combination with information on the degree of among-population isolation, is a better predictor of the degree of isozyme variability than range size alone.

Biogeographical patterns of genetic diversity in Pilgerodendron were compared with those in the other two Cupressaceae from temperate South America: Fitzroya cupressoides (Molina) I. M. Johnst. and Austrocedrus chilensis (D. Don) Florin \& Boutelje. These are monotypic genera included in the monophyletic subfamily Callitroideae, which consists of genera with Southern Hemisphere distributions (Gadek et al., 2000). The three genera characterize floristically the Subantarctic 
Province within the Antarctic region (Cabrera \& Willink, 1980), which in turn is considered to be a biogeographic island, given its isolation dating to the Tertiary, from other similar Southern Hemisphere floras (Armesto et al., 1995).

Pilgerodendron, Fitzroya, and Austrocedrus are 'endemic species sensu lato, which means that they belong exclusively to one place or region' (Rapoport, 1982; pp. 14-15), in this case, the temperate forests of southern Argentina and Chile. In addition, given that they have very different patterns of geographical distributions, the distinction between widespread and geographically restricted will be considered in relation to the overall range of the biogeographical region. Thus, the concepts of endemism and geographical range are used here in relative terms. Pilgerodendron has the most extended latitudinal distribution of any tree species in temperate South America, whereas Fitzroya and Austrocedrus occur over more restricted geographical ranges but consist of larger and more continuous populations, particularly in the case of Austrocedrus. It is predicted that Pilgerodendron will have lower genetic variation and greater among-population differentiation than Fitzroya and Austrocedrus, despite the greater geographical range of Pilgerodendron.

The aim of this study is to analyse the following questions. (i) What are the levels of isozyme variation in populations of Pilgerodendron? (ii) What is the degree of among-population differentiation in this species? (iii) How does this information relate to that measured in closely related species which have different patterns of geographical distributions?

\section{The species}

Pilgerodendron (common names: ciprés de las Guaitecas, ciprés de las islas o Ten; indigenous mapuche name: Lahuán) is a long-lived conifer endemic to southern Chile and the adjacent parts of Argentina. Although restricted to wet and poorly drained sites, its overall geographical range extends over $1600 \mathrm{~km}$ from $39^{\circ} 36^{\prime}$ to $54^{\circ} 20^{\prime} \mathrm{S}$ (Szeicz et al., 2000), making it the world's southern-most conifer and having the most extended natural distribution of any tree species in temperate South America. Whereas in Chile it covers a total area of 564922 ha (CONAF et al., 1999), in Argentina it is less abundant, and is only found at scattered sites from $41^{\circ} 00^{\prime} \mathrm{S}$ to $50^{\circ} 19^{\prime} \mathrm{S}$ and from $71^{\circ} 25^{\prime} \mathrm{W}$ to $73^{\circ} 13^{\prime} \mathrm{W}$ (Rovere et al., pers. comm.). At its northern-most limit it occurs as isolated populations in the Chilean Coastal range and on both slopes of the Andes, becoming more abundant to the south, characterizing the Chilean Archipelagos south of $44^{\circ} \mathrm{S}$.

\section{Materials and methods}

Twenty populations of Pilgerodendron (12 from Chile and eight from Argentina) were sampled across the species' geographical range (Table 1). Thirty individuals, separated by a minimum of $50 \mathrm{~m}$, were randomly

\begin{tabular}{rlcrr}
\hline No. & \multicolumn{1}{c}{ Population } & $\begin{array}{c}\text { Latitude } \\
\text { (south) }\end{array}$ & $\begin{array}{c}\text { Longitude } \\
\text { (west) }\end{array}$ & $\begin{array}{r}\text { Altitude } \\
\text { (m a.s.l.) }\end{array}$ \\
\hline 1 & San Pablo de Tregua & $39^{\circ} 36^{\prime} 08^{\prime \prime}$ & $72^{\circ} 05^{\prime} 80^{\prime \prime}$ & 800 \\
2 & Chaiten & $43^{\circ} 21^{\prime} 20^{\prime \prime}$ & $72^{\circ} 23^{\prime} 53^{\prime \prime}$ & 600 \\
3 & Puyehue & $40^{\circ} 45^{\prime} 96^{\prime \prime}$ & $72^{\circ} 17^{\prime} 13^{\prime \prime}$ & 745 \\
4 & Corral & $39^{\circ} 55^{\prime} 88^{\prime \prime}$ & $73^{\circ} 27^{\prime} 07^{\prime \prime}$ & 450 \\
5 & Estaquillas & $41^{\circ} 25^{\prime} 04^{\prime \prime}$ & $73^{\circ} 46^{\prime} 81^{\prime \prime}$ & 40 \\
6 & Lago Tepuhueco & $42^{\circ} 49^{\prime} 11^{\prime \prime}$ & $73^{\circ} 55^{\prime} 21^{\prime \prime}$ & 100 \\
7 & Puerto Ayen & $45^{\circ} 23^{\prime} 69^{\prime \prime}$ & $72^{\circ} 55^{\prime} 43^{\prime \prime}$ & 40 \\
8 & Senda Darwin & $41^{\circ} 52^{\prime} 93^{\prime \prime}$ & $73^{\circ} 39^{\prime} 18^{\prime \prime}$ & 40 \\
9 & Tepual & $41^{\circ} 25^{\prime} 60^{\prime \prime}$ & $73^{\circ} 04^{\prime} 08^{\prime \prime}$ & 95 \\
10 & San José & $39^{\circ} 45^{\prime} 28^{\prime \prime}$ & $73^{\circ} 05^{\prime} 13^{\prime \prime}$ & 20 \\
11 & Alerce Andino & $41^{\circ} 30^{\prime} 56^{\prime \prime}$ & $72^{\circ} 37^{\prime} 00^{\prime \prime}$ & 360 \\
12 & Lago Vargas & $47^{\circ} 36^{\prime} 61^{\prime \prime}$ & $72^{\circ} 55^{\prime} 43^{\prime \prime}$ & 170 \\
13 & Puerto Blest & $41^{\circ} 02^{\prime} 28^{\prime \prime}$ & $71^{\circ} 48^{\prime} 11^{\prime \prime}$ & 761 \\
14 & Laguna Hito & $42^{\circ} 39^{\prime} 76^{\prime \prime}$ & $71^{\circ} 46^{\prime} 86^{\prime \prime}$ & 595 \\
15 & Bahía Cipresales & $50^{\circ} 05^{\prime} 33^{\prime \prime}$ & $73^{\circ} 13^{\prime} 71^{\prime \prime}$ & 272 \\
16 & Los Alerces & $42^{\circ} 40^{\prime} 06^{\prime \prime}$ & $71^{\circ} 47^{\prime} 34^{\prime \prime}$ & 631 \\
17 & Puerto Camiseta & $50^{\circ} 32^{\prime} 51^{\prime \prime}$ & $72^{\circ} 55^{\prime} 78^{\prime \prime}$ & 204 \\
18 & Punta Bandera & $50^{\circ} 19^{\prime} 14^{\prime \prime}$ & $72^{\circ} 49^{\prime} 21^{\prime \prime}$ & 227 \\
19 & Cordón Serrucho & $41^{\circ} 45^{\prime} 29^{\prime \prime}$ & $71^{\circ} 25^{\prime} 68^{\prime \prime}$ & 958 \\
20 & Ortiz Basualdo & $41^{\circ} 00^{\prime} 03^{\prime \prime}$ & $71^{\circ} 50^{\prime} 40^{\prime \prime}$ & 900 \\
\hline
\end{tabular}

Table 1 Location of sampled populations of Pilgerodendron uviferum in southern Chile (1-12) and Argentina (13-20) 
selected from each population. In the case of the smallest sampled population, located in Punta Bandera within the Glaciares National Park (Argentina), more than one sample (1, 2 or 4 twigs) was collected from each of the 14 clumps, to determine if each clump was clonal in origin. From each individual, approximately $20 \mathrm{~cm}$ of twig with fresh leaf tissue was collected, and the samples were kept cool until they were taken to the laboratory, where they were stored at $0-4^{\circ} \mathrm{C}$. Enzyme extracts were prepared by crushing approximately $500 \mathrm{mg}$ of leaf tissue in liquid nitrogen to which $1 \mathrm{~mL}$ of extraction buffer (Mitton et al., 1979) was added. Homogenates were centrifuged and stored at $-80^{\circ} \mathrm{C}$ until they were absorbed onto Whatman No. 3 paper wicks that were loaded into $12 \%$ starch gels.

Two buffer systems, morpholine-citrate $\mathrm{pH} 7.5$ (Ranker et al., 1989) and histidine-tris pH 7.0 (King \& Dancik, 1983), were run at constant currents of 20 and $35 \mathrm{~mA}$, respectively, for about $5 \mathrm{~h}$ or until the marker dye had migrated at least $8 \mathrm{~cm}$ from the origin. Anodal slices were cut horizontally and stained for enzyme activity using the agarose-staining methods of Mitton et al. (1979) and Soltis et al. (1983). Aconitase (ACO, EC 4.2.1.3), isocitrate dehydrogenase (IDH, EC 1.1.1.42), malic enzyme (ME, EC 1.1.1.40), peroxidase (PER, EC 1.11.1.7), 6-phosphogluconate dehydrogenase (6PGD, EC 1.1.1.44), phosphoglucose isomerase (PGI, EC 5.3.1.9), phosphoglucomutase (PGM, EC 5.4.2.2), and shikimate dehydrogenase (SKDH, EC 1.1.1.25) were separated using morpholine-citrate buffers, whereas malate dehydrogenase $(\mathrm{MDH}, \mathrm{EC}$ 1.1.1.37) was separated using histidine-tris buffers. The scoring of isozymes genotypes consisted of assigning consecutive numbers so that the most anodal locus and/or allele were designated with the lowest numeral. Loci are considered putative since no genetic analysis was performed, although gel banding patterns and interpretation of results were similar to those obtained in other plant species (Murphy et al., 1996).

Within-population isozyme variation was described by standard gene diversity measures using POPGENE v. 1.31 (Yeh et al., 1999). These measures were the proportion of polymorphic loci using 0.95 and 0.99 criteria $(P<0.95$ and $P<0.99)$, the mean number of alleles per locus $(A)$, and the observed and expected heterozygosities ( $H_{\mathrm{O}}$ and $H_{\mathrm{E}}$, respectively).

Deviations of polymorphic loci from the HardyWeinberg equilibrium were analysed using chi-squared tests. Population genetic structure was measured by $F$-statistics (Wright, 1965) using FSTAT v. 2.9.1. (Goudet, 2000) which computes unbiased estimates. Total genetic diversity at a locus $\left(H_{\mathrm{T}}\right)$ and genetic diversity within populations $\left(H_{\mathrm{S}}\right)$ were calculated using 11 polymorphic loci, according to Nei (1973). These indices were compared to those of the geographically restricted Fitzroya, using the same loci from published data by Premoli et al. (2000a,b), which in turn were obtained using similar sampling schedules as in Pilgerodendron. Significant differences in the levels of among-population divergence $\left(F_{\mathrm{ST}} \sim G_{\mathrm{ST}}\right)$ were analysed using $95 \%$ confidence intervals generated by bootstrapping over loci. Between-species comparisons in the levels of within-population variation and genetic diversity were analysed using the nonparametric Mann-Whitney Rank Sum Test, with populations and loci as factors, respectively. Data on Austrocedrus were available from only one population, so no statistical comparison was performed with this species.

\section{Results}

For Pilgerodendron, $78 \%(11 / 14)$ of the resolved putative isozyme loci were polymorphic ( 0.95 criterion $)$ in at least one population. However, approximately half of the polymorphic loci were polymorphic in only one population (Table 2). At the species level and for the 14 loci, $A$ averaged 2.3 alleles per locus and the expected heterozygosity was 0.035 . Population-level polymorphism was on average only $11.4 \%$ and $17.1 \%$ with the 0.95 and 0.99 criteria, respectively, not exceeding $36 \%$ and $43 \%$ for each criterion in any population. Reduced within-population isozyme variability was also measured by $A$ with 1.2 alleles per locus, and mean heterozygosities were 0.024 and 0.033 for $H_{\mathrm{O}}$ and $H_{\mathrm{E}}$,

Table 2 Electrophoretic analyses of populations of Pilgerodendron uviferum

\begin{tabular}{lll}
\hline Locus & \multicolumn{1}{c}{ Results } & $\begin{array}{c}\text { No. polymorphic } \dagger \\
\text { populations for each locus } \\
\text { (population number }\end{array}$ \\
\hline Aco & Monomorphic & \\
Idh & Polymorphic & $5(4,5,7,10,16)$ \\
$M e-1$ & Polymorphic & $1(8)$ \\
$M e-2$ & Polymorphic & $1(3)$ \\
Per-1 & Polymorphic & $5(7,9,10,11,15)$ \\
Per-2 & Polymorphic & $1(9)$ \\
$6 P g d-1$ & Polymorphic & $1(3)$ \\
$6 P g d-2$ & Monomorphic & $1(6)$ \\
Pgi-1 & Polymorphic & $7(3,5,8,10,11,13,20)$ \\
Pgi-2 & Polymorphic & $3(9,10,16)$ \\
Pgm & Polymorphic & $2(3,4)$ \\
Skdh-1 & Polymorphic & \\
Skdh-2 & Monomorphic & $6(2,3,4,6,9,16)$ \\
$M d h$ & Polymorphic & \\
\hline
\end{tabular}

$\dagger$ Corresponds to 0.95 criterion.

\$For population names see Table 1. 
Table 3 Genetic variability at 14 isozyme loci in 20 populations of Pilgerodendron uviferum (standard errors in parentheses). $P<0.95$ and $P<0.99$ represent the proportion of polymorphic loci with the 0.95 and 0.99 criteria, respectively, $A$ is the mean number of alleles per locus, and $H_{\mathrm{O}}$ and $H_{\mathrm{E}}$ are the observed and expected heterozygosities, respectively

\begin{tabular}{lccccc}
\hline Population & $P<0.95$ & $P<0.99$ & $A$ & $H_{\mathrm{O}}$ & $H_{\mathrm{E}}$ \\
\hline 1. San Pablo de Tregua & 0 & 7.1 & $1.1(0.0)$ & $0.002(0.002)$ & $0.011(0.011)$ \\
2. Chaiten & 7.1 & 7.1 & $1.1(0.0)$ & $0.010(0.010)$ & $0.023(0.023)$ \\
3. Puyehue & 35.7 & 42.9 & $1.5(0.1)$ & $0.055(0.025)$ & $0.096(0.036)$ \\
4. Corral & 21.4 & 35.7 & $1.4(0.1)$ & $0.071(0.060)$ & $0.101(0.046)$ \\
5. Estaquillas & 14.3 & 14.3 & $1.1(0.1)$ & $0.007(0.007)$ & $0.039(0.026)$ \\
6. Lago Tepuhueco & 14.3 & 21.4 & $1.2(0.1)$ & $0.012(0.010)$ & $0.042(0.027)$ \\
7. Puerto Ayen & 14.3 & 14.3 & $1.2(0.1)$ & $0.076(0.069)$ & $0.044(0.038)$ \\
8. Senda Darwin & 14.3 & 21.4 & $1.3(0.1)$ & $0.021(0.021)$ & $0.033(0.021)$ \\
9. Tepual & 28.6 & 35.7 & $1.5(0.1)$ & $0.052(0.022)$ & $0.053(0.022)$ \\
10. San Jose & 21.4 & 28.6 & $1.3(0.1)$ & $0.055(0.034)$ & $0.074(0.034)$ \\
11. Alerce Andino & 14.3 & 14.3 & $1.1(0.1)$ & $0.031(0.024)$ & $0.027(0.021)$ \\
12. Lago Vargas & 0 & 14.3 & $1.1(0.1)$ & $0.005(0.003)$ & $0.005(0.003)$ \\
13. Puerto Blest & 7.1 & 21.4 & $1.3(0.1)$ & $0.012(0.008)$ & $0.016(0.011)$ \\
14. Laguna Hito & 0 & 0 & $1.0(0.0)$ & $0.000(0.000)$ & $0.000(0.000)$ \\
15. Bahía Cipresales & 7.1 & 7.1 & $1.1(0.1)$ & $0.017(0.017)$ & $0.015(0.015)$ \\
16. Los Alerces & 21.4 & 21.4 & $1.2(0.1)$ & $0.033(0.029)$ & $0.048(0.029)$ \\
17. Puerto Camiseta & 0 & 0 & $1.0(0.0)$ & $0.000(0.000)$ & $0.000(0.000)$ \\
18. Punta Bandera & 0 & 14.3 & $1.1(0.1)$ & $0.002(0.002)$ & $0.007(0.005)$ \\
19. Cordón Serrucho & 0 & 0 & $1.0(0.0)$ & $0.000(0.000)$ & $0.000(0.000)$ \\
20. Ortiz Basualdo & 7.1 & 21.4 & $1.2(0.1)$ & $0.017(0.010)$ & $0.030(0.023)$ \\
Population averages & $11.4(2.3)$ & $17.1(2.7)$ & $1.2(0.0)$ & $0.024(0.005)$ & $0.033(0.007)$ \\
Species values & 14.3 & 42.9 & 2.3 & 0.023 & 0.035 \\
\hline
\end{tabular}

respectively (Table 3). Variable phenotypes were obtained between samples within clumps at Punta Bandera, indicating that at least some individual clumps were not the result of vegetative spread.

Observed genotypic frequencies deviated significantly from Hardy-Weinberg expectations in $48 \%$ of possible comparisons, $87 \%$ of which (data not shown) gave positive fixation indices. Estimates of $F$-statistics by jackknifing over loci yielded average values of 0.394 $(\mathrm{SE}=0.165)$ and $0.284(\mathrm{SE}=0.204)$ for $F_{\mathrm{IT}}$ and $F_{\mathrm{IS}}$, respectively. The $95 \%$ confidence interval for $F_{\text {IS }}$ $(-0.042$ to 0.646$)$ indicated that, on average, observed heterozygotes did not differ significantly from expectation, suggesting no significant inbreeding effects in Pilgerodendron. The analysis of genetic structure indicated that most of the genetic diversity is found within populations $\left(H_{\mathrm{T}}=0.050, H_{\mathrm{S}}=0.042\right)$ and the degree of differentiation among populations measured by $F_{\mathrm{ST}}$ was $16 \%$ (Table 4).

Whereas the mean number of alleles per locus for Pilgerodendron was only 1.2, for Austrocedrus it was 1.7 (Ferreyra et al., 1996), and for Fitzroya it was 1.5 (Premoli et al., 2000b). The same pattern was found for expected heterozygosity and polymorphism ( 0.99 criterion), with population-level averages of 0.071 and $41 \%$ for Austrocedrus (Ferreyra et al., 1996), 0.077 and 33\% for Fitzroya (Premoli et al., 2000b), and only 0.033 and
Table 4 Measures of genetic diversity $\left(H_{\mathrm{T}}\right.$ and $H_{\mathrm{S}}$, total and within-populations, respectively) and among-population divergence $\left(F_{\mathrm{ST}}\right)$ for the widespread Pilgerodendron uviferum (20 populations and 11 polymorphic loci) compared to the geographically restricted Fitzroya cupressoides (24 populations and 11 polymorphic loci). Mean, standard errors (in parenthesis), and 95\% confidence intervals (in brackets) for $F_{\mathrm{ST}}$ were computed by resampling methods. Different letters indicate significant differences $(P<0.05$, Mann-Whitney Rank Sum Test $)$

\begin{tabular}{lccc}
\hline Species & $H_{\mathrm{T}}$ & $H_{\mathrm{S}}$ & $F_{\mathrm{ST}}$ \\
\hline Pilgerodendron uviferum & $0.039^{\mathrm{a}}$ & $0.033^{\mathrm{a}}$ & $0.159(0.032)$ \\
& & & {$[0.094-0.214]$} \\
Fitzroya cupressoides $\dagger$ & $0.160^{\mathrm{b}}$ & $0.147^{\mathrm{b}}$ & $0.078(0.014)$ \\
& & & {$[0.050-0.108]$}
\end{tabular}

$\dagger$ Data from Premoli et al. (2000b).

$17 \%$ for Pilgerodendron, respectively (all tests between Fitzroya and Pilgerodendron, $P<0.05$, Mann-Whitney Rank Sum Test). Estimates of genetic diversity indicated that total genetic diversity, as well as the withinpopulation component, was significantly greater in Fitzroya, whereas Pilgerodendron had greater amongpopulation divergence (Table 4) (data for Austrocedrus not available). Mean $F_{\mathrm{ST}}$ for Pilgerodendron was twice 
as high as that for Fitzroya, and although they partially coincided in their $95 \%$ confidence intervals, Pilgerodendron's upper value exceeded that of Fitzroya.

\section{Discussion}

Reduced isozyme variation was detected within populations of Pilgerodendron uviferum compared to the other two members of the Cupressaceae from southern Argentina and Chile, Austrocedrus chilensis and Fitzroya cupressoides, which have more restricted geographical distributions. Pilgerodendron is the conifer with the most widespread overall geographical range in temperate South America and thus, as suggested by reviews of isozyme data in plants (e.g. Hamrick \& Godt, 1989; Hamrick et al., 1992), higher levels of isozyme variation would have been expected relative to more geographically restricted species. However, our results were not surprising given that although Pilgerodendron has the most extended latitudinal range, it consists of scattered and small populations, commonly restricted to particular habitats such as periglacial environments, lowland bogs, and wetlands. Austrocedrus, in contrast, is found in a wide array of habitats, from temperate wet forests, to Mediterranean-type environments, as well as near the foreststeppe ecotone in Patagonia. Fitzroya, on the other hand, usually grows in humid areas where annual precipitation ranges from $2000 \mathrm{~mm}$ to $4000 \mathrm{~mm}$, occurs at different elevations from $\approx 100 \mathrm{~m}$ to $1200 \mathrm{~m}$, and on different soil types, from poorly drained soils, to incipient soils of volcanic origin, and well developed loamy soils (Veblen et al., 1995). Thus, in comparison to Pilgerodendron, Austrocedrus and Fitzroya generally consist of larger and more continuous populations, and as a result, may maintain elevated polymorphism and among-population gene flow. Our results are consistent with Donoso's (1995; p. 55) observations on Pilgerodendron, which predicted that habitat-restricted species, occurring in isolated populations, would tend to be genetically monomorphic.

Although many woody species maintain relatively high levels of genetic variability (Hamrick \& Godt, 1996), some examples exist of widespread conifers with limited genetic variation, such as Pinus resinosa (Fowler \& Morris, 1977) and Tsuga canadensis (Zabinski, 1992), with 0 and $10 \%$ polymorphism, respectively. The most common explanation for the reduction or absence of isozyme variation is that each species has gone through one or more population bottlenecks. The reduced polymorphism and partial inbreeding measured in populations of Pilgerodendron, may be explained in terms of locally surviving populations that were isolated throughout the last Glacial Maximum during the Pleistocene and which suffered the effects of past population bottlenecks and reduced gene flow.
The results presented here are similar to those using RAPD variation for some of the same Pilgerodendron populations analysed here and for a subset of Fitzroya populations studied by Premoli et al. (2000a,b). The analysis of 16 populations of Pilgerodendron yielded lower polymorphism (35.7\%, Allnutt et al., pers. comm.) than that recorded in 12 populations of Fitzroya (72.4\%, Allnutt, pers. comm.). In addition, AMOVA analysis of RAPD variation indicated that a greater proportion of the total variation was found among different populations of Pilgerodendron $(18.55 \%$, Allnutt et al., pers. comm.) than in Fitzroya (14.38\%, Allnutt et al., 1999).

Data for species of Nothofagus (southern beech) from temperate South America in the subgenus Nothofagus, which in turn forms a monophyletic group (Manos, 1997), also show a similar pattern to that found for the comparison between Pilgerodendron and Fitzroya. The widespread $N$. pumilio, which is distributed from $35^{\circ}$ to $55^{\circ} \mathrm{S}$ latitude but is locally restricted to high-elevation forests, showed reduced polymorphism and greater among-population divergence than $N$. dombeyi, which also has a wide range $\left(35^{\circ}\right.$ to $\left.48^{\circ} \mathrm{S}\right)$ but consists of more continuous populations. A comparative analysis using isozyme loci indicated that $N$. dombeyi is significantly more variable than $N$. pumilio, with a mean number of alleles per locus of 1.6 vs. 1.2, a polymorphism ( 0.95 criterion) of 25 vs. $13 \%$, observed heterozygosities of 0.082 vs. 0.019 , and expected heterozygosities of 0.093 vs. 0.03 in $N$. dombeyi vs. $N$. pumilio, respectively (all tests $P<0.05$, Whitney Rank Sum Test). In addition, based on seven polymorphic loci, mean $F_{\mathrm{ST}}$ values were 0.180 for $N$. dombeyi and 0.312 for $N$. pumilio, suggesting greater among-population divergence in the latter (calculated from Premoli, 1997, 1998).

Other studies using isozymes have yielded similar results in trees; for example, the rare Pacific yew (Taxus brevifolia) which occurs over a wide range but is sparsely distributed and never abundant, indicated low polymorphism $(<50 \%)$ and moderate among-population divergence $\left(G_{\mathrm{ST}} \approx 10 \%\right)$ (Scher, 1996). In contrast, Pinus echinata, with a wide range and wide habitat requirements, had high polymorphism $(54 \%)$ and lower divergence among populations $\left(G_{\mathrm{ST}}=9 \%\right.$; Rajiv et al., 1997). In addition, species with restricted range but consisting of disjunct populations, also had elevated levels of total diversity found among different populations, such as Pinus pungens $\left(G_{\mathrm{ST}}=13.5 \%\right.$; Gibson \& Hamrick, 1991), P. radiata $\left(G_{\mathrm{ST}}=16 \%\right.$; Moran et al., 1988), P. halepensis $\left(G_{\mathrm{ST}}=30 \%\right.$; Schiller et al., 1986), and $P$. cembra $\left(G_{\mathrm{ST}}=32 \%\right.$; Szmidt, 1982). Overall, it was suggested that the level of genetic heterogeneity among populations of pine species is greater in species with geographically disjunct populations than in those 
with more continuous distributions (Hamrick \& Godt, 1996). However, the relationship between divergence and polymorphism with geographical range and continuity of their populations was not explored.

Geographical range has been considered a good predictor of the levels of genetic variation in plant populations (Hamrick \& Godt, 1989). However, and particularly in the case of woody species, the geographical range only accounted for $44.5 \%$ of the total variation $(34 \%)$ that was explained by a multiple regression model, which included other life-history traits (Hamrick et al., 1992). One potential limitation of the explanatory power of these models may be related to the fact that pooling information from unrelated taxa with dissimilar life histories makes generalizations difficult (Karron, 1987). It has been suggested that paired comparisons between congeners may increase the probability that restricted and widespread species have similar ecological features and phylogenetic histories (Karron, 1987, 1997; Gitzendanner \& Soltis, 2000). Therefore, measured genetic differences can be attributed to the characteristics (such as geographical range) in which they differ. From the analysis of 11 pairs of congener species, rare species had significantly lower levels of genetic variation than their widespread congeners (Karron, 1987). In addition, for the 34 pairs of congeners examined by the review of Gitzendanner \& Soltis (2000), different indicators of isozyme variation were significantly lower in the rare than in the widespread species. However, although some rare species maintained reduced genetic variation, they had a large range of values, exceeding those of widespread congeners in some cases. Furthermore, the available species' pairs did not differ significantly, as in the analysis done by Hamrick \& Godt (1989), in the estimates of total genetic diversity $\left(H_{\mathrm{T}}\right)$ or in the degree of amongpopulation differentiation measured by $F_{\mathrm{ST}} \sim G_{\mathrm{ST}}$. All this information suggests that geographical range alone may not be adequate in predicting levels of polymorphism and divergence between populations.

It has been suggested that species which are considered rare may exhibit a diverse array of total ranges, population sizes, and habitat specificity resulting in seven different types of rarity (Rabinowitz, 1981). As a result, rare species with different attributes may maintain different levels and patterns of genetic diversity (Premoli et al., 1999; Gitzendanner \& Soltis, 2000). For example, based on overall geographical distribution alone, Pilgerodendron can be considered widespread, whereas sensu Rabinowitz it could be classified as a rare species with a wide range but occurring in disjunct habitats along the Andes, which is expected to affect the levels of variability and the degree of among-population divergence. Thus, we suggest that available genetic information on species should be examined not just in relation to overall geographical distribution, but also with respect to range continuity.

\section{Acknowledgements}

We are grateful to the National Parks in both Chile and Argentina for facilitating our work in protected areas. We thank R. Vergara and J.C. Aravena for sample collections of Chilean populations, A. Rovere for sample collections of Argentinean populations, and $\mathrm{M}$. Caldiz for field and laboratory assistance. Discussions with J. Armesto, R. Ennos, and A. Lara greatly improved the formulation of the concepts included in our manuscript. We thank John Brookfield and two anonymous reviewers for insightful comments and suggestions. This research was supported by the European Commission-funded project SUCRE (Sustainable Use, Conservation and Restoration of Native Forest in southern Chile and Argentina and south-central Mexico), Framework IV of DGXII, contract number ERBIC18CT970146. A.P. is supported by CONICET (Consejo Nacional de Investigaciones Científicas y Técnicas de Argentina).

\section{References}

Allnutt, T. R., NeWton, A. C., LARA, A., PRemoli, A. C., ARMESTO, J. J., VERGARA, R. ET AL. 1999. Genetic variation in Fitzroya cupressoides (alerce) a threatened South American conifer. Mol. Ecol., 8, 975-987.

ARMeSto, J. J., LEON LOBOS, P. AND ARROYO, M. K. 1995. Temperate forests of southern Chile and Argentina: a biogeographic island. In: Armesto, J. J., Villagrán, C. and Arroyo, M. K. (eds) Ecología de Los Bosques Nativos de Chile, pp. 23-28. Editorial Universitaria, Santiago, Chile.

CABrerA, A. L. AND Willink, A. 1980. Biogeografía de América Latina, 2nd edn. The General Secretariat of the Organization of American States Monograph no. 13. Washington DC.

CONAF, CONAMA, BIRF, UNIVERSIDAD AUSTRAL DE CHILE, PONTIFICIA UNIVERSIDAD CATÓLICA DE CHILE, UNIVERSIDAD CATÓlica de temuCo. 1999. Catastro y Evaluación de los Recursos Vegetacionales Nativos de Chile. Informe Nacional con Variables Ambientales. Santiago, Chile.

DONOso, C. 1995. Bosques Templados de Chile y Argentina: Variación, Estructura y Dinámica, 3rd edn. Editorial Universitaria, Santiago, Chile.

FERREYRA, L. I., LATINO, A., CALDERON, A. AND CARDENAL, C. N. 1996. Allozyme polymorphism in Austrocedrus chilensis (D. Don.) Florin et Boutelje from Patagonia, Argentina. Silvae Genet., 45, 61-64.

FOWLER, D. P. AND MORRIS, R. W. 1977. Genetic diversity in red pine: evidence for low heterozygosity. Can. J. Forest Res., 7, 341-347.

GADEK, P. A., AlPERS, D. L., HESLEWOOD, M. M. AND QUINN, C. J. 2000. Relationships within Cupressaceae sensu lato: a com- 
bined morphological and molecular approach. Am. J. Bot., 87, 1044-1057.

GIBSON, J. P. AND HAMRICK, J. L. 1991. Genetic diversity and structure in Pinus pungens (Table Mountain pine) populations. Can. J. Forest Res., 21, 635-642.

GITZENDANNER, M. A. AND SOLTIS, P. S. 2000. Patterns of genetic variation in rare and widespread plant congeners. Am. J. Bot., 87, 783-792.

GOUDET, J. 2000. FSTAT. A program to estimate and test gene diversities and fixation indices. Release 2.9.1. Université de Lausanne, Dorigny, Switzerland.

HAMRICK, J. L. AND GODT, M. J. W. 1989. Allozyme diversity in plant species. In: Brown, A. H. D., Clegg, M. T., Kahler, A. L. and Weir, B. S. (eds) Plant Population Genetics, Breeding, and Genetic Resources, pp. 43-63. Sinauer Associates, Sunderland, MA.

HAMRICK, J. L. AND GODT, M. J. W. 1996. Conservation genetics of endemic plant species. In: Avise, J. C. and Hamrick, J. L. (eds) Conservation Genetics, Case Histories from Nature, pp. 281-304. Chapman \& Hall, New York.

HAMRICK, J. L., GODT, M. J. W. AND SHERMAN-BROYLES, S. L. 1992. Factors influencing levels of genetic diversity in woody plant species. New Forests, 6, 95-124.

KARRON, J. D. 1987. A comparison of levels of genetic polymorphism and self-compatibility in geographically restricted and widespread plant congeners. Evol. Ecol., 1, 47-58.

KARRON, J. D. 1997. Genetic consequences of different patterns of distribution and abundance. In: Kunin, W. E. and Gaston, K. J. (eds) The Biology of Rarity, pp. 174-189. Chapman \& Hall, London.

KING, J. N. AND DANCIK, B. P. 1983. Inheritance and linkage of isozymes in white spruce (Picea glauca). Can. J. Genet. Cytol., 5, 430-436.

MANOS, P. S. 1997. Systematics of Nothofagus (Nothofagaceae) based on rDNA spacer sequences (ITS): taxonomic congruence with morphology and plastid sequences. Am. J. Bot., 84, 1137-1155.

MITTON, J. B., LINHART, Y. B., STURGEON, K. B. AND HAMRICK, J. L. 1979. Allozyme polymorphisms detected in mature needle tissue of ponderosa pine. J. Hered., 70, 86-89.

MORAN, G. F., BELL, J.C. AND ELDRIDGE, K. G. 1988. The genetic structure and conservation of the five natural populations of Pinus radiata. Can. J. Forest Res., 18, 506-514.

MURPHY, R. W., SITES, J. W. JR, BUTH, D. G. AND HAUFLER, C. H. 1996. Proteins: isozyme electrophoresis. In: Hillis, D. M., Moritz, C. and Mable, B. K. (eds) Molecular Systematics, pp. 51-120. Sinauer Associates, Sunderland, MA.

NEI, M. 1973. Analysis of gene diversity in subdivided populations. Proc. Natl. Acad. Sci. U.S.A., 70, 3321-3323.

PREMOLI, A. C. 1997. Genetic variation in two widespread and a geographically restricted species of South American. Nothofagus. J. Biogeogr., 24, 883-892.

PREMOLI, A. C. 1998. The use of genetic markers to conserve endangered species and to design protected areas of more widespread species. In: International Foundation for Science (ed.) Proceedings of an International Workshop: Recent Advances in Biotechnology for Tree Conservation and
Management, pp. 157-171. Universidade Federal de Santa Catarina, Florianópolis, Santa Catarina, Brazil.

PREMOLI, A. C., SOUTO, C. P., NEWTON, A. C. AND ALLNUTT, T. R. 1999. Form of rarity affects levels of within-population isozyme variation in an endangered conifer. 13th Annual Meeting of the Society for Conservation Biology, MD.

PREMOLI, A. C., KITZBERGER, T. AND VEBLEN, T. T. 2000a. Isozyme variation and recent biogeographical history of the long-lived conifer Fitzroya cupressoides. J. Biogeogr., 27, 251-260.

PREMOLI, A. C., KITZBERGER, T. AND VEBLEN, T. T. $2000 \mathrm{~b}$. Conservation genetics of the endangered conifer Fitzroya cupressoides in Chile and Argentina. Conserv. Genet., 1, $57-66$.

RABINOWITZ, D. 1981. Seven forms of rarity. In: Synge, H. (ed.) The Biological Aspects of Rare Plant Conservation, pp. 205-217. John Wiley \& Sons, Chichester, U.K.

RAJIV, R. G., TAUER, C. G., WITTWER, R. F. AND HUANG, Y. 1997. Isoenzyme variation and genetic structure in natural populations of shortleaf pine (Pinus echinata). Can. J. Forest Res., 27, 740-749.

RANKER, T. A., HAUfleR, C. H., SOltis, P. S. AND SOltis, D. E. 1989. Genetic evidence for allopolyploidy in the neotropical fern Hemionitis (Adiantaceae) and the reconstruction of an ancestral genome. Syst. Bot., 14, 439-447.

RAPOPORT, E. H. 1982. Areography: Geographical Strategies of Species. Pergamon Press, Oxford.

SCHER, S. 1996. Genetic structure of natural Taxus populations in western North America. In: Smith, T. B. and Wayne, R. K. (eds) Molecular Genetic Approaches in Conservation, pp. 424-441. Oxford University Press, New York.

SCHILLER, G., CONKLE, M. T. AND GRUMWALD, C. 1986. Isozyme variation among native stands and plantations of aleppo pine in Israel. Isr. J. Bot., 35, 161-174.

SOLTIS, D. E., HAUFLER, C. H., DARROW, D. C. AND GASTONY, G. J. 1983. Starch gel electrophoresis of ferns: a compilation of grinding buffers, gel and electrode buffers, and staining schedules. Am. Fern J., 73, 9-27.

SZEICZ, J. M., LARA, A., DÍAZ, S. AND ARAVENA, J. C. 2000. Dendrochronological studies of Pilgerodendron uviferum in southwestern South America. In: Roig, F. A. (ed.) Dendrocronología en América Latina, pp. 245-270. EDIUNC, Mendoza, Argentina.

SZMIDT, A. E. 1982. Genetic variation in isolated populations of stone pine (Pinus cembra). Silva Fenn., 16, 196-200.

VEBLEN, T. T., BURNS, B. R., KITZBERGER, T., LARA, A. AND VILlALBA, R. 1995. The ecology of the conifers of southern South America. In: Enright, N. J. and Hill, R. S. (eds) Ecology of the Southern Conifers, pp. 120-155. Melbourne University Press, Carlton, Victoria.

WRIGHT, S. 1965. The interpretation of population structure by $F$-statistics with special regard to systems of mating. Evolution, 19, 395-420.

YEH, F. C., YANG, R. AND BOYLE, T. 1999. POPGENE. Microsoft Windows-based freeware for population genetic analysis. Release 1.31. University of Alberta, Edmonton.

ZABINSKI, C. 1992. Isozyme variation in eastern hemlock. Can. J. Forest Res., 22, 1838-1842. 